\title{
EVALUASI PELAKSANAAN PROSES PEMBELAJARAN GAMBAR TEKNIK KELAS XI TITL DI SMK NEGERI 3 SINGARAJA
}

\author{
I. M. Wira Purnawan 1 , I. N. Santiyadnya ${ }^{2}$, I. W. Sutaya ${ }^{3}$ \\ ${ }^{1}$ Prodi Pendidikan Teknik Elektro, Universitas Pendidikan Ganesha, Singaraja \\ 2,3Prodi Teknik Elektronika, Universitas Pendidikan Ganesha, Singaraja \\ e-mail: wirapurnawan4@gmail.com, santiyadnya@undiksha.ac.id, wsutaya@undiksha.ac.id
}

\begin{abstract}
Abstrak
Penelitian ini, bertujuan untuk mendeskripsikan tentang bagaimana pelaksanaan proses pembelajaran gambar teknik kelas XI teknik instalasi tenaga listrik (TITL) di SMK Negeri 3 Singaraja. Penelitian ini meliputi perencanaan, pelaksanaan, dan evaluasi proses pembelajaran gambar teknik. Penelitian ini menggunakan metode kualitatif deskriptif, sumber data penelitian yaitu dua orang guru dan empat orang siswa TITL. Teknik pengumpulan yang digunakan seperti : metode wawancara, observasi, dan studi dokumentasi. Hasil data kemudian dianalisis dengan reduksi data, penyajian data, dan kesimpulan/verifikasi. Berdasarkan analisis data, didapatkan hasil seperti : 1) perencanaan proses pembelajaran, guru A dan B menyusunan RPP lebih dari tiga RPP. Komponen RPP sesuai dengan instruksi kurikulum 2013, namun kurang pembagian alokasi waktu pada langkah-langkah kegiatan, guru mempersiapakan administrasi pembelajaran dan siswa mempersiapkan perlengkapan belajar. 2) pelaksanaan proses pembelajaran, guru A dan B kurang sesuai dengan RPP yang disusun. Kegiatan pendahuluan, guru tidak memberikan motivasi, kegiatan inti guru kurangnya pengelolaan kelas dan kurang tegas menyampaikan materi, dan kegiatan penutup guru tidak menyimpulkan materi yang disampaikan. 3) evaluasi proses pembelajaran guru lebih banyak memberikan nilai keterampilan dan tidak pernah memberikan tugas sesuai dengan pengakuan siswa $A, B, C$, dan D.
\end{abstract}

Kata kunci: evaluasi, proses pembelajaran, Gambar Teknik.

\begin{abstract}
This study, aims to describe how the implementation of the learning process engineering drawing class XI Teknik Instalasi Tenaga Listrik (TITL) at SMK Negeri 3 Singaraja. This study includes the planning, implementation, and evaluation of the learning process engineering drawings. This study uses a qualitative method descriptif, source of research data, namely two teachers and four students TITL. Collection techniques used such as: interviews, observation and documentation study. The results of the data then analyzed using data reduction, data display, and conclusion/verification. Based on data analysis, the result such as:1) planning of learning process, teachers $A$ and $B$ arranged RPP more than three RPP. . RPP component in accordance with the instruction curriculum in 2013, but less distribution of the allocation of time on the steps of activities, learning administration preparing teachers and students prepare for school supplies. 2) the implementation of the learning process, the teacher $A$ and $B$ is less prepared in accordance with the RPP. Preliminary activities, the teacher does not provide motivation, lack of teacher's core activities and less classroom management firm delivering materials, and activities cover teachers do not conclude the material presented. 3) evaluation of the learning process more teachers value the skills and never leave a task in accordance with the recognition of students $A, B, C$, and $D$.
\end{abstract}

Keywords: Evaluation, Learning Process, Technical Drawing.

\section{Pendahuluan}

Menurut UU RI No. 18 tahun 2002 ilmu pengetahuan adalah rangkaian pengetahuan yang digali, disusun, dan dikembangkan secara sistematis dengan menggunakan pendekatan tertentu yang dilandasi oleh metodologi ilmiah, baik yang bersifat kuantitatif, kualitatif, maupun eksploratif untuk menerangkan pembuktian gejala alam dan gejala kemasyarakatan tertentu. Untuk mengem- bangkan pengetahuan juga dibutuhkan teknologi yang menunjang agar pengetahuan bisa diterapkan di dunia kerja. Teknologi adalah kumpulan alat, termasuk mesin, modifikasi, pengaturan dan prosedur yang digunakan oleh manusia.

Dalam UU RI No. 18 tahun 2002 teknologi adalah cara atau metode serta proses atau produk yang dihasilkan dari penerapan dan pemanfaatan berbagai disiplin ilmu pengetahuan 
yang mengha- silkan nilai bagi pemenuhan kebutuhan, kelangsungan, dan peningkatan mutu kehidupan manusia.

Sehubungan dengan perkem- bangan ilmu pengetahuan dan teknologi yang melaju dengan cepat, maka lembaga pendidikan dituntut untuk berbenah diri, baik dari segi kegiatan belajar mengajar yang meliputi dari lingkup formal, non formal dan informal. Pendidikan adalah usaha sadar dan terencana untuk mewujudkan suasana belajar dan proses pembelajaran agar peserta didik secara aktif mengembangkan potensi dirinya untuk memiliki kekuatan spiritual keagamaan, pengendalian diri, kepri- badian, kecerdasan, akhlak mulia, serta keterampilan yang diperlukan dirinya, masyarakat, bangsa dan negara dalam UU RI No. 20 tahun 2003.

Jalur pendidikan adalah wahana yang dilalui peserta didik untuk mengembangkan potensi diri dalam suatu proses pendidikan yang sesuai dengan tujuan pendidikan. Jenjang pendidikan adalah tahapan pendidikan yang ditetapkan berdasarkan tingkat perkem- bangan peserta didik, tujuan yang akan dicapai, dan kemampuan yang dikembangkan dalam UU RI No. 20 tahun 2003. Pendidikan formal berkaitan dengan instansi pendidikan baik itu sekolah maupun perguruan tinggi. Dari instansi ini dapat dilihat yang memberikan pengetahuan dan teknologi sebagai bagian dari pendidikan. Berkaitan dengan IPTEK instansi pendidikan yang umunnya dilaksanakan dijenjang sekolah terutama sekolah menengah kejuruan (SMK). Baik dalam SMK diberikan IPTEK melalui proses pembelajaran di dalam kelas baik secara teori maupun praktik. Pembelajaran adalah suatu kombinasi yang tersusun meliputi unsur- unsur manusiawi, material, fasilitas, perleng- kapan, dan prosedur yang saling mempengaruhi mencapai pembelajaran Sistem pembelajaran dapat dilaksanakan dengan cara membaca buku, belajar di kelas atau di sekolah, karena diwarnai oleh organisasi dan interaksi antara berbagai komponen yang saling berkaitan, untuk membelajarkan peserta didik (Hamalik,2011).

Berkaitan dengan proses pembelajaran yang dilakukan di sekolah menengah kejuruan, siswa yang mengambil Jurusan Teknik Instalasi Tenaga Listrik. Dalam proses pem-belajaran tentang kelistrikan tentu akan banyak menemui simbol-simbol komponen listrik, maka dari itu perlu adanya pembelajaran gambar teknik. Dalam kurikulum 2013 gambar teknik tidak lagi menggambar simbol-simbol komponen melainkan gambar potongan suatu benda. Dalam pelaksanaan pembelajaran gambar teknik beberapa siswa atau peserta didik yang tidak membawa perlengkapan untuk gambar, misalnya seperti buku gambar yang sesuai ukuran, pensil, penggaris untuk gambar teknik, penghapus dan lain-lainnya. Siswa yang tidak membawa perlengkapan tersebut akan mengganggu siswa yang lainnya dengan meminjam peralatan yang dibawa sehingga mengganggu dalam proses pembelajaran terutama dalam menyelesaikan gambar, dengan demikian masalah tersebut akan menimbulkan masalah yang berikutnya seperti kelas menjadi tidak kondusif. Dalam keadaan seperti itu peran guru sangat penting dalam mengatur keadaan kelas agar suasana belajar menjadi kondusif, namun dalam mengatur siswa yang karakternya berbeda-beda bukan kendala yang mudah, dengan demikian penulis termotivasi untuk melakukan penelitian yang berjudul "Evaluasi Pelaksanaan Proses Pembelajaran Gambar Teknik Kelas XI Jurusan Teknik Instalasi Tenaga Listrik (TITL) di SMK Negeri 3 Singaraja". Berdasarkan latar belakang masalah yang telah diuraikan di atas, dapat dirumuskan permasalahan penelitian sebagai berikut : 1) Bagaimana Perencanaan proses pembelajaran gambar teknik dikelas XI TITL?, 2) Bagaimana Pelaksanaan proses pembelajaran gambar teknik di kelas XI TITL ?, 3) Bagaimana evaluasi pelaksanaan proses pembelajaran gambar teknik?. Dari permasalahan tersebut, tujuan dari penelitian ini adalah sebagai berikut. 1) Untuk mengetahui perencanaan proses pembelajaran gambar teknik. 2) Untuk mengetahui pelaksanaan proses pembelajaran gambar teknik. 3) Untuk mengetahui evaluasi yang digunakan dalam pembelajaran gambar teknik.

Landasan teori yang digunakan dalam penelitian ini seperti evaluasi, proses pembelajaran, dan gambar teknik. Evaluasi merupakan proses penilaian pertumbuhan siswa dalam proses belajar mengajar. Pencapaian perkembangan siswa perlu diukur, baik posisi siswa sebagai individu maupun posisinya dalam kegiatan kelompok. Hal yang demikian perlu disadari oleh seorang guru karena pada umumnya siswa masuk kelas dengan kemampuan bervariasi. Kegiatan evaluasi dalam proses belajar mengajar mempunyai beberapa 
karakteristik penting, salah satunya yaitu memiliki implikasi tidak langsung terhadap siswa yang dievaluasi. Hal ini terjadi misalnya seorang guru melakukan penilaian terhadap kemampuan yang tidak tampak dari siswa. Apa yang dilakukan adalah dia lebih banyak menafsir melalui beberapa asfek penting yang diizinkan seperti melalui penampilan, keterampilan, atau reaksi mereka terhadap suatu stimulus yang diberikan secara terencana. Disamping karakteristik, evaluasi juga mempunyai fungsi yang bervariasi di dalam proses belajar mengajar, salah satunya yaitu : sebagai alat guna mengetahui apakah peserta didik telah menguasai pengetahuan, nilai-nilai, dan keterampilan yang telah diberikan oleh seorang guru. Dalam bidang pendidikan, beberapa prinsip evaluasi dapat dilihat seperti berikut ini. 1) Evaluasi harus masih dalam kisi-kisi kerja tujuan yang telah ditentukan. 2) Evaluasi sebaiknya dilaksanakan secara komprehensif. 3) Evaluasi diselenggarakan dalam proses yang kooperatif antara guru dan peserta didik. 4) Evaluasi dilaksanakan dalam proses berkelanjutan. 5) Evaluasi harus peduli dan mempertimbangkan nilai-nilai yang berlaku. Suatu evaluasi perlu memenuhi bebebrapa syarat sebelum diterapkan kepada siswa yang kemudian direfleksikan dalam bentuk tingkah laku. Evaluasi yang baik, harus mempunyai syarat seperti berikut: 1) valid, 2) andal, 3) objektif, 4) seimbang, 5) membedakan, 6) norma, 7) fair, dan 8) praktis. Minimal terdapat enam tujuan evaluasi dalam kaitannya dengan belajar mengajar salah satunya adalah menilai ketercapaian (attainment) tujuan. Ada ketertarikan antara tujuan belajar, metode evaluasi, dan cara belajar siswa. Cara evaluasi biasanya akan menentukan cara belajar siswa, sebaliknya tujuan evaluasi akan menentukan metode evaluasi yang digunakan oleh seorang guru (Sukardi:2008).

Evaluasi program adalah metode untuk mengetahui dan menilai efektivitas suatu program dengan membandingkan kriteria yang telah ditentukan atau tujuan yang ingin dicapai dengan hasil yang dicapai. Hasil yang dicapai dalam bentuk informasi digunakan sebagai bahan pertimbangan untuk pembuatan keputusan dan penentuan kebijakan (Djemari,2012: 33). Dalam evaluasi ada banyak model yang bisa digunakan untuk mengevaluasi suatu program. Meski modelnya berbeda, namun maksudnya sama yaitu melakukan kegiatan pengumpulan data yang berkenaan dengan objek yang dievaluasi, yang bertujuan untuk menyediakan bahan bagi pengambilan keputusan (Arikunto, 2014). Pasal 88 ayat (1) UU RI No. 20 tahun 2003 tentang sisdiknas, yang menyatakan evaluasi hasil belajar peserta didik dilakukan oleh pendidik untuk memantau proses kemajuan dan perbaikan hasil belajar peserta didik secara berkesi- nambungan.

Pembelajaran adalah suatu kombinasi yang tersusun meliputi unsur- unsur manusiawi, material, fasilitas, perlengkapan, dan prosedur yang saling mempengaruhi mencapai pembelajaran (Hamalik, 2011: 57). Perencanaan proses pembelajaran meliputi Silabus dan Rencana Pelaksanaan Pembelajaran (RPP) yang memuat identitas mata pelajaran, Standar Kompetensi, Kom- petensi Dasar (KD), indikator pencapaian kompetensi, tujuan pembelajaran, materi ajar, alokasi waktu, metode pembelajaran, penilaian hasil belajar, dan sumber belajar. Pelaksanaan proses pem- belajaran merupakan inplementasi dari Rencana Pelaksanaan Pembelajaran. Penilaian dilakukan oleh guru terhadap hasil pembelajaran untuk mengukur tingakat pencapaian kompetensi peserta didik, serta digunakan sebagai bahan penyusunan laporan kemajuan hasil belajar, dan memperbaiki proses pembelajaran (Rusman, 2012).

Gambar teknik adalah gambar yang digunakan untuk merencanankan sebuah objek atau (design) yang akan rancang, dibangun atau dipasang. Diketahi bahwa gambar teknik telah dipergunakan, karena orang tidak dapat membuat rencana dan membangun seperti yang mereka telah lakukan tanpa menggunakan gambar yang cukup akurat (Giesecke, 2000). Dalam pembelajaran gambar teknik di jurusan teknik instalasi tenaga lisrtik mempelajari gambar potongan dari suatu benda dengan materi gambar potongan. Dalam materi gambar potongan, banyak sekali elemen-elemen benda dimana bagian dalamnya memiliki rongga. Untuk mengggambarkan bagian benda yang tidak langsung terlihat seperti rongga tersebut dapat digunakan garis putus-putus (Herli,2014). 


\section{Metode}

Metode penelitian kualitatif adalah metode penelitian yang berlandaskan pada filsafat postpositivisme, digunakan untuk meneliti pada kondisi obyek yang alamiah, (sebagai lawannya adalah eksperimen) dimana peneliti sebagai instrumen kunci, pengambilan sampel sumber data dilakukan secara purposive dan snowbaal, teknik pengumpulan dengan trianggulasi (gabungan), analisa data bersifat induktif atau kualitatif, dan hasil penelitian kualitatif lebih mene- kankan makna dari generalisasi. Penelitian kualitatif instrumennya adalah orang atau human instrument, yaitu peneliti itu sendiri untuk dapat menjadi instrumen, maka peneliti harus memiliki bekal teori dan wawasan yang luas, sehingga mampu bertanya, menganalisis, memotret, dan menkontruksi situasi sosial yang diteliti menjadi lebih jelas dan bermakna (Sugiyono, 2015: 15).

Dalam penelitian kualitatif ini peneliti meng- gunakan model evaluasi, adapun model evaluasi yang digunakan adalah Countenance Evaluation Model dikem- bangkan oleh Stake, dalam Arikunto (2008:48) model stake menekankan pada adanya pelaksanaan dual hal pokok, yaitu: (1) deskripsi (description) dan (2) per- timbangan (judgments); serta membedakan tiga tahap evaluasi program, yaitu: (1) antesenden (antecen- dents/context), (2) transaksi (transaction /process), (3) keluaran (output-outcomes). Penelitian ini dilaksanakan di SMK Negeri 3 Singaraja pada bidang keahlian kompetensi kelistrikan atau jurusan Teknik Instalasi Tenaga Listrik (TITL). SMK Negeri 3 Singaraja dipilih sebagai tempat penelitian karena tempat penelitian berada di daerah kota singaraja sehingga memudahkan peneliti untuk menjangkau tempat penelitian. Penelitian kualitatif, peneliti memasuki situasi sosial tertentu, yang dapat berupa lembaga pendidikan tertuntu, melakukan observasi dan wawancara kepada orangorang yang dipandang tahu tentang situasi sosial tersebut. Penentuan sumber data pada orang yang diwawancarai dilakukan secara purposive, yaitu dipilih dengan pertimbanganpertimbangan dan tujuan tertentu (Sugiono,2015). Sumber data dalam penelitian ini adalah guru jurusan TITL yang mengajar mata pelajaran gambar teknik, siswa kelas XI TIPTL sesuai pertimbangan dan tujuan dari penelitian ini. Peneliti memilih sumber data berdasakan masalah atau gejala yang ingin diungkapkan untuk mendapatkan Informasi atau data yang akan digunakan sebagai bahan pertimbangan untuk

pembuatan ke- putusan dan penentuan kebijakan.

Data penelitian yang didapatkan data mentah dari hasil instrumen penelitian yang digunakan peneliti. Dari hasil wawancara yang dilakukan peneliti dengan guru akan mendapatkan hasil dari kesiapan guru dalam pelaksanaan proses pembelajaran yang meliputi perencanaan, pelaksanaan, dan evaluasi pembelajaran, hasil data yang didapatkan ditulis dalam catatan peneliti. Dari hasil wawancara kepada siswa akan mendapatkan hasil kesiapan siswa dalam mengikuti pem- belajaran dan persiapan siswa dalam mengikuti pembelajaran. peneliti menggunakan metode dokumentasi untuk mendapatkan data dalam bentuk gambar, atau karya-karya, dan dokumen per- lengkapan pengajaran. Dalam penelitian ini kehadiran peneliti sangat penting karena peneliti juga bertindak sebagai instrumen pengumpulan data. Dalam proses pengumpulan data peneliti menggunakan metode observasi, wawancara, dan dokumentasi untuk mendapatkan data dari sumber data. Adapun instrumen yang digunakan peneliti untuk mendapatkan data berupa pedoman observasi, pedoman wawancara dan dokumentasi. Untuk mendapatkan data penelitian, maka peneliti menggunakan pedoman wawancara. Pedoman wawancara ini digunakan peneliti sebagai panduan dalam mengumpulkan informasi atau mendapatkan data dari obyek (Sugiyono, 2015).

Teknik pengumpulan data dapat dilakukan dengan observasi (penga- matan), interview (wawancara), koesioner (angket), dokumentasi dan gabungan /triangulasi. Dalam penelitian kualitatif, pengumpulan data dilakukan pada natural setting (kondisi yang alamiah), sumber data primer, dan teknik pengumpulan data lebih banyak pada observasi ber- peranserta (participan observation), wawancara mendalam (in depth interview), dan dokumentasi (Sugiyono, 2015:308-309). Adapun teknik pengum- pulan data yang digunakan dalam penelitian ini adalah sebagai berikut: 1) observasi, Marshall dalam Sugiono, (2015) menyatakan bahwa "throurgh observation, the researcher learn about behhavior and the maening attached to those behavior". Melalui observasi, peneliti belajar tentang perilaku, dan makna dari perilaku tersebut. 2) Esterberg dalam Sugiyono, (2015: 317) Wawancara adalah 
merupakan pertemuan dua orang untuk bertukar informasi dan ide melalui tanya jawab, sehingga dapat dikonstruksikan makna dalam suatu topik. 3) Dokumen merupakan catatan peristiwa yang sudah berlalu. Dokumen bisa berbentuk tulisan, gambar, atau karya-karya monumental dari seseorang. Dokumen yang berbentuk tulisan misalnya catatan harian, sejarah kehidupan (life histories), cerita, biografi, peraturan, kebijakkan.

Analisis data adalah proses mencari dan menyusun secara sistematis data yang diperoleh dari hasil wawancara, catatan lapangan,dan dokumentasi, dengan cara mengorganisasikan data ke dalam kategori, menjabarkan ke dalam unit-unit melakukan sintesa, menyusun kedalam pola, memilih mana penting dan yang akan dipelajari, dan membuat kesimpulan sehingga mudah dipahami oleh diri sendiri maupun orang lain (Sugiyono,2015). Nasution dalam Sugiyono,(2015:336) menyatakan "Ana- lisis telah mulai sejak merumuskan dan menjelaskan masalah, sebelum terjun ke lapangan, dan berlangsung terus sampai penulisan hasil penelitian". Namun dalam

penelitian kualitatif, analisis data lebih difokuskan selama proses di lapangan bersamaan dengan bersamaan dengan pengumpulan data. Penelitian kualitatif telah melakukan analisi data sebelum peneliti memasuki lapangan. Analisa dilakukan terhadapat data hasil studi pendahuluan, atau data sekunder, yang digunakan akan digunakan untuk menentukan fokus penelitian ini masih bersifat sementara, dan berkembang setelah peneliti masuk dan selama di lapangan. Miles and Huberman dalam Sugiyono,(2015 : 337), mengemukakan bahwa aktifitas dalam analisa data kualitatif dilakukan secara interaktif dan berlangsung secara terus menerus sampai tuntas, sehingga datanya sudah jenuh. Aktivitas dalam analisa data, yaitu data reduction, data display, dan conclusion drawing/verification.

a. Data Reduction (Reduksi Data)

Data yang diperoleh dari lapangan jumlahnya cukup banyak, untuk itu perlu dicatat secara teliti dan rinci. Seperti telah dikemukakan, makin lama peneliti ke lapangan, maka jumlah data akan makin banyak, kompleks dan rumit. Untuk itu perlu segera dilakukan analisis data melalui reduksi data. Mereduksi data berarti merangkum, memilih hal-hal yang pokok, memfokuskan pada hal-hal yang penting, dicari tema dan polanya dan membuang yang tidak penting. Dengan demikian data yang telah direduksi akan memberikan gambaran yang lebih jelas, dan mempermudah peneliti untuk melakukan pengumpulan data selan- jutnya, dan mencarinya bila diperlukan.

b. Data Display (Penyajikan Data)

Setelah data direduksi, maka langkah selanjutnya adalah mendis- playkan data. Dalam penelitian kualitatif, penyajian data bisa dilakukan dalam bentuk uraian singkat, bagan, hubungan antar katagori, flowchart dan sejenisnya.

c. Conclusion Drawing/Verification

Langkah ke tiga dalam analisis kualitatif menurut Miles dan Huberman dalam Sugiyono, (2015:345) adalah penarikan kesimpulan data dan verifikasi. Kesimpulan awal yang dikemukakan masih bersifat sementara, dan akan berubah bila tidak ditemukan bukti-bukti yang kuat yang mendukung pada tahap pengumpulan data berikutnya.

\section{Hasil dan Pembahasan}

Berdasarkan hasil reduksi data wawancara, observasi, dan studi dokumentasi silabus mata pelajaran gambar teknik tidak disusun oleh guru yang mengajar tetapi disusun oleh pemerintah pusat. Silabus mata pelajaran gambar teknik sebagai pedoman dan acuan guru dalam menuyusun rencana pelaksanaan pembelajaran (RPP). Peyusunan RRP oleh guru tergantung pada kompetensi dasar yang ada dalam silabus, jadi dalam satu mata pelajaran guru menyusun tiga atau lebih RPP yang digunakan. Hal ini sesuai dengan pernyataan Permendikbud No. 22 tahun 2016 yang menyatakan Rencana Pelaksanaan Pembelajaran (RPP) adalah rencana kegiatan pembelajaran tatap muka untuk satu pertemuan atau lebih. Penyusunan RPP oleh guru berbasis kurikulum 2013, dimana terdapat tiga aspek yang digunakan yaitu aspek sikap, aspek pengetahuan, aspek keterampilan. ketiga aspek ini dimuat dalam kompetensi inti (KI), KI-1 (sikap spritual), KI-2 (sikap sosial), KI-3 (pengetahuan), dan $\mathrm{KI}-4$ (keterampilan). 
Dalam menyusun RPP guru merencanakan model pembelajaran yang akan digunakan, karena sekolah kejuruan lebih banyak mendapatkan praktik dari pada teori seperti gambar tenik jadi guru mengunakan model pemberajaran inkuiri dan berbasi proyek dengan pendekatan saintifik. Hal ini sesuai dengan Permendikbud No. 22 tahun 2016 yang menyatakan Untuk memperkuat pendekatan ilmiah (scientific), tematik terpadu (tematik antar mata pelajaran), dan tematik (dalam suatu mata pelajaran) perlu diterapkan pembelajaran berbasis penyingkapan/penelitian (discovery/inquiry learning). Untuk mendorong kemampuan peserta didik untuk menghasilkan karya kontekstual, baik individual maupun kelompok maka sangat disarankan menggunakan pendekatan pembelajaran yang menghasilkan karya berbasis pemecahan masalah (project based learning).

Penyusunan RPP yang dilakukan oleh guru, terdapat komponen- komponen RPP sebagai berikut 1) identitas, 2) alokasi waktu, 3) kompentensi inti (KI), 4) kompetensi dasar $(\mathrm{KD}), 5)$ tujuan pembelajaran, 6) materi pelajaran, 7) metode pembelajaran, , 8) media, alat dan sumber pembelajaran, 9) kegiatan pembelajaran, 10) penilaian. Berdasarkan reduksi data yang dilakukan pada RPP yang dibuat oleh guru yang berpedoman pada silabus kurang sesuai dengan Permendikbud No. 22 tahun 2016 hal ini diperkuat dengan teori (Rusman,2012:4) karena ada kekurangan dalam dalam RPP yang dibuat oleh guru yaitu pada langkah-langkah kegiatan dimana dalam langkah kegiatan ini tidak berisikan alokasi waktu pada masing-masing kegiatan. Sehingga pada kegiatan pendahuluan, kegiatan inti, dan kegiatan penutup guru hanya memperkirakan waktu yang digunakan pada masing-masing kegiatan, dan pada materi pelajaran seharusnya diisi judul materi atau inti pokok dari materi yang diajarkan.

Berdasarkan reduksi data penelitian, adapun administrasi yang dipersiapkan guru dalam perencanaan pembelajaran gambar teknik seperti silabus, program tahunan (prota), program semester (promes), rencana pelaksanaan pembelajaran (RPP). Berdasarkan reduksi data perlengkapan yang dipersiapkan siswa A, B, C dan D seperti buku gambar, alat-alat gambar seperti penggaris segitiga, pensil, penghapus, penggaris mal, dan jangka. Namum dalam pembelajaran gambar teknik siswa pernah tidak membawa salah satu peralatan tersebut dan bahkan tidak membawa peralatan sama sekali.

Pelaksanaan pembelajaran dilak- sanakan kurang sesuai dengan RRP yang telah disusun oleh guru, karena Pelaksanaan proses pembelajaran merupakan inplementasi dari Rencana Pelaksanaan Pembelajaran. (Rusman, 2012:13). Hal ini sama dengan Permendikbud No. 22 tahun 2016 juga menyatakan Pelaksanaan pembelajaran merupakan implementasi dari RPP. Menurut pernyataan permendikbud No. 22 tahun 2016 dengan RPP yang disusun memberikan motivasi belajar kepada siswa belum terlaksana di kegiatan pendahuluan. Alokasi waktu yang diberikan dalam kegiatan pendahuluan juga tidak ada, karena dalam RPP yang disusun tidak ada pembagian waktu pada langkah- langkah kegiatan di RPP. Pada kegiatan inti guru memulai proses pembelajaran dengan mengondisikan kelas untuk tercapainya tujuan, indikator sesuai dengan kompetensi dasa. Dalam pelaksanaan kegiatan inti pembelajaran gambar teknik menggunakan model pembelajaran inkuri dan project based learning karena dalam kegiatan inti siswa lebih banyak melakukan praktik dari pada mendapatkan teori dalam pembelajaran, sesusi dengan Permendikbud No. 22 tahun 2016. Pelaksanaan proses pem- belajaran guru kurang dalam pengelolan kelas, hal ini diperkuat dengan teori dalam Syaiful, (2006:173) masalah pokok yang dihadapi guru, baik pemula maupun yang sudah berpengalaman adalah penge- lolaan kelas.

Pengelolaan kelas merupakan masalah tingkah laku yang kompleks, dan guru menggunakannya untuk menciptakan dan mempertahankan kondisi kelas sedemikian rupa sehingga anak didik dapat mencapai tujuan pengajaran secara efisien dan memu- ngkinkan mereka dapat belajar, dengan demikian pengelolaan kelas yang efektif adalah syarat bagi pengajaran yang efektif. Tugas utama dan paling sulit bagi guru adalah pengelolaan kelas, pengelolaan kelas adalah keterampilan guru untukmenciptakan dan memelihara kondisi belajar yang optimal dan mengembalikannya bila terjadi gangguan dalam proses belajar mengajar, untuk itu guru perlu melakukan pendekatan dalam pengelolaan kelas yaitu menggunakan pendekatan ancaman sesuai dengan teori Syaiful, (2006:179) pendekatan ancaman atau intimidasi pengelolaan kelas adalah suatu proses untuk mengontrol tingkah laku anak didik. Tetapi dalam mengontrol tinggah laku anak didik dilakukan dengan cara memberikan ancaman, misalnya melarang, ejekan, sindiran, dan memaksa. Dalam menutup 
pembelajaran guru sangar jarang menyimpulkan hasil kegiatan belajar menagar yang telah dilaksanakan dan ini kurang sesuai dengan RPP yang disusun dan Permendikbud No. 22 tahun 2016. Dari hasil observasi dan wawancara guru tidak memberikan tugas secara individu maupun kelopok dalam penutupan pembelajaran.

Menurut Permendikbud No. 22 tahun 2016 menyatakan evaluasi hasil pembelajaran dilakukan saat proses pembelajaran dan di akhir satuan pelajaran dengan menggunakan metode dan alat: tes lisan/perbuatan, dan tes tulis. Hasil evaluasi akhir diperoleh dari gabungan evaluasi proses dan evaluasi hasil pembelajaran. Evaluasi pelaksanaan proses pembelajaran ini belum dilakukan secara maksimal, dikarenakan penilaian keterampilan dilakukan lebih banyak dari pada penilaian pengetahuan dan penilaian sikap. Dalam penilaian pengetahuan jarang guru meberikan soal uraian, baik itu pilihan ganda maupun esai dan pertanyaan-pertanyaan karena fokus terhadap pengerjaan gambar.

\section{Simpulan dan Saran}

Berdasarkan hasil penelitian dan pembahasan dapat disimpulkan sebagai berikut. Dalam perencanaan proses pem- belajaran guru dan siswa, penyusunan RPP dan komponenkomponen RPP yang disusun oleh guru A dan B kurang sesuai dengan Permendikbud No. 22 tahun 2016. RPP yang disusun menggunakan kurikulum 2013, karena terdapat sedikit kekurangan dalam penyusunan RPP yang disusun guru yaitu dalam langkah-langkah kegiatan tidak disusun alokasi waktu dan materi pelajaran tidak diisi pokok-pokok atau sub judul mater pelajaran.

Dalam pelaksanaan proses pembelajaran guru kurang sesuai dengan RPP yang disusun, karena Pelaksanaan proses pembelajaran merupakan inplementasi dari Rencana Pelaksanaan Pembelajaran. Pada kegiatan penda- huluan guru A dan B kurang memberikan motivasi kepada siswa sesuai dengan RPP yang disusun. Dalam kegiatan inti guru kurang dalam pengelolaan kelas agar keadaan kelas tetap kondusif dalam pelaksanaan proses pembelajaran. Kegiatan penutup guru tidak menyimpulkan kegiatan yang sudah terlaksana dan tidak pernah memberikan tugas kepada siswa.

Dalam evaluasi proses pem- belajaran kurang sesuai dengan RPP yang disusun karena sesuai dengan pengakuan siswa $A, B, C$, dan $D$ mengatakan guru jarang memberikan tes pengethauan hanya pada pertengahan dan diakhir semerter. Dari hasil penelitian dan pembahasan yang sudah disimpulkan, saran yang dapat diberikan adalah sebagai berikut. Dalam perencanaan proses pembelajaran, penyusunan RPP harus lengkap dengan pembagian alokasi waktu pada langkah-langkah kegiatan supaya alokasi waktu 2 jam pelajaran dapat dimanfaatkan sebaik mungkin.

Dalam pelaksanaan proses pembelajaran guru harus sesui dengan RPP yang disusun. Guru harus memberikan motivasi kepada siswa agar siswa semangat dalam belajar dan lebih meningkatkan pengelolaan kelas saat proses pembelajaran. Dalam evaluasi proses pembelajaran, guru harus memberikan sedikit waktu dalam melakukan penilaian pengetahuan seperti tes tulis maupun pilihan ganda untuk mengetahuai tingkat pemahaman dan perkembangan siswa.

\section{Daftar Pustaka}

Arikunto, Suharsimi, dan Abdul Jabar, Cepi Safruddin. 2014. Evaluasi Program Pendidikan: Pedoman Teoretis Praktis Bagi Mahasiswa dan Praktisi Pendidikan. Jakarta: Bumi Aksara

Bhari Djamara, syaiful dan Zai Aswan. 2006. Strategi Belajar Mengajar. Jakarta : PT. Rineka Cipta

Giesecke, DKK. 2000. Gambar Teknik. Jakarta: Erlangga

Hamalik, Oemar. 2011. Kurikulum dan Pembelajaran. Jakarta: Bumi Aksara 
Herli, Novia Rinjan. 2014. Rencana Pelaksanaan Pembelajaran: Gambar Tenik. (tidak diterbitkan) : SMK Negeri 3 Singaraja

Kementriaan Pendidikan dan Kebudayaan 2016. Peraturan Mentri Pendidikan dan Kebudayaan Nomer 22 tahun 2016 tentang Standar Proses Pendidikan Dasar dan Menengah

Kementriaan Pendidikan dan Kebudayaan 2016. Peraturan Mentri Pendidikan dan Kebudayaan Nomer 23 tahun 2016 tentang Standar Penilaian Pendidikan

Mardapi, Djamari. 2012. Pengukuran, Penilian, \& Evaluasi Pendidikan. Yogyakarta: Nuha Medika

Sugiyono. 2015. Metode Penelitian Pendidikan (Pendekatan Kuantitatif, Kualitatif, dan R\&D). Bandung: Alfabeta

Sukardi, H.M. 2008. Evaluasi Pendidikan Prinsip \& Operasionalnya. Yogyakarta: Bumi Aksara

Undang-Undang Republik Indonesia, Nomer 20 Tahun 2003 tentang sistem pendidikan nasional.http://kelembagaan.ristekdikti.go.id/wpcontent/uploads/2016/08/UU_no_20_t h_2003.pdf diakses pada 2 oktober 2017

Undang-Undang Republik Indonesia, Nomer 18 Tahun 2002 tentang sistem nasional penelitian, pengembangan, dan penerapan ilmu pengetahuan dan teknologi. http://risbang.ristekdikti.go.id/regulasi/uu-18-2002.pdf diakses pada 2 oktober 2017 